\title{
Towards a Conceptual Understanding of Groundwater Ecology
}

By

H.O Nwankwoala ${ }^{1}$

\begin{abstract}
In recent times, ecohydrology and hydroecology are making a mark on the environmental agenda, as evidenced by the proliferation of these terms in the academic literature. There is an increasing recognition that groundwater is essential to many ecological communities. Surface ecological processes (such as evapotranspiration) significantly impact hydrological responses and related hydrochemical function. Thus, the relation of groundwater hydrology to patterns and processes in ecology is a 'two-way street' where understanding the feedback of one to the other serves as a powerful lens through which to evaluate and explain the functioning of natural ecosystems. Influxes of groundwater to lakes, rivers, and wetlands can change whole-system physico-chemical properties such as temperature and salinity, while also providing more subtle influences on microenvironments and their ecological processes. The recognition of the significance and power of this tandem has not always been followed with effective interdisciplinary science. The ecological, hydrological, and physico-chemical links between groundwater, surface water and associated ecosystems are seldom fully understood even though true characterization and wise management will require a multidisciplinary approach. This means biologists need to understand the importance of magnitude and timing of groundwater flows for their system, which requires the skills of hydrogeologists to achieve. Hydrogeologists, in turn, must understand how and why groundwater influences ecological processes so that their expertise is brought to bear at a scale commensurate to the ecological research question. In this paper therefore, an overview of general concepts, research efforts and future perspectives are presented. More importantly, the paper asserts that it is not simply the integration of hydrology and ecology that will determine the future prospects for ecohydrology/hydroecology, but the way in which this integrative science is conducted.
\end{abstract}

Keywords: Ecology, groundwater, ecohydrology, hydroecology, hydrogeoecology, Wetlands, microbial processes. 


\section{Introduction}

The recent integration of groundwater sciences, including hydrogeology and groundwater biology, addresses groundwater ecology at the landscape scale (Danielopol et al., 2007) and this is in tandem with the recent recognition that biological diversity of groundwater is much greater than formerly appreciated and much more widespread (Sket, 1999; Wilkens et al., 2000; Danielopol \& Pospisil, 2000).

Hydrogeoecology is a term describing studies focusing on groundwater-ecology interaction. Similar to 'hydrogeology' and residing within the larger study of 'hydrology', hydrogeoecology can be thought of as a subset within the broader field of 'hydroecology', the study of interactions between the hydrology of all water bodies and their ecological components. The need to raise strong awareness among hydrogeologists of the importance of groundwater to a range of ecosystem-related questions, and consequences of hydrogeological decisions is emphasized in this paper. Moreso, there is the urgent need to enhance understanding of hydrogeology amongst biologists as this decipline provides the template, or abiotic "box", within which ecological processes play out.

Integration of groundwater ecology, biogeochemistry, geomicrobiology, and hydrogeology will significantly advance our understanding of subterranean ecosystems, especially in terms of bioremediation of contaminated groundwaters, improvement/maintenance of surface water quality in groundwater-dependent ecosystems as well as improved protection of groundwater habitats/ biodiversity conservation during the extraction of natural resources. Above all, this will ultimately lead to a better understanding of the implications of groundwater hydrology and aquifer geology to distributions of subsurface fauna and microbiota, ecological processes such as carbon cycling, and more importantly, sustainable management of groundwater resources. This paper therefore discusses the opportunities/ future perspectives of hydrogeological and ecological research to address management problem, as well as explores the issues concerned with the subterranean part of the water cycle from the perspective of the biology of invertebrate animals that live of necessity in groundwater, the obligate inhabitants, as well as their microbiological milieu. The paper also advocates a truly interdisciplinary (as opposed to multidisciplinary) approach in which ecologists and hydrologists benefit from true synergy by embracing advances at the cuttingedge of both sciences. Such an approach should provide more perceptive answers to hydroecological/ecohydrological problems and management questions. 


\section{Evolution of Groundwater Ecology}

Groundwater ecology has evolved from a science describing the unique subterranean biota to its current form emphasizing multidisciplinary studies that integrate hydrogeology and ecology. According to Danielopol, (1994) Groundwater ecology is the study of the interactions between groundwater organisms and their external environment, be it the immediate aquifer or a connected terrestrial system. The evolution of groundwater ecology can be traced back to 1541, with a description of the blind fish Sinocyclocheilus byalinus in the Alu Limestone caves in Yunnam, China (Romero, 2001). Chapelle (2001), reported that as early as 1926 in Sunset-Midway Oilfield, California, U.S.A, there was evidence that active microorganisms lived in groundwater.

In 1962, the fundamental link between groundwater quality and microbial activity was described (Gurevich, 1962), and in the ensuing years, the role that

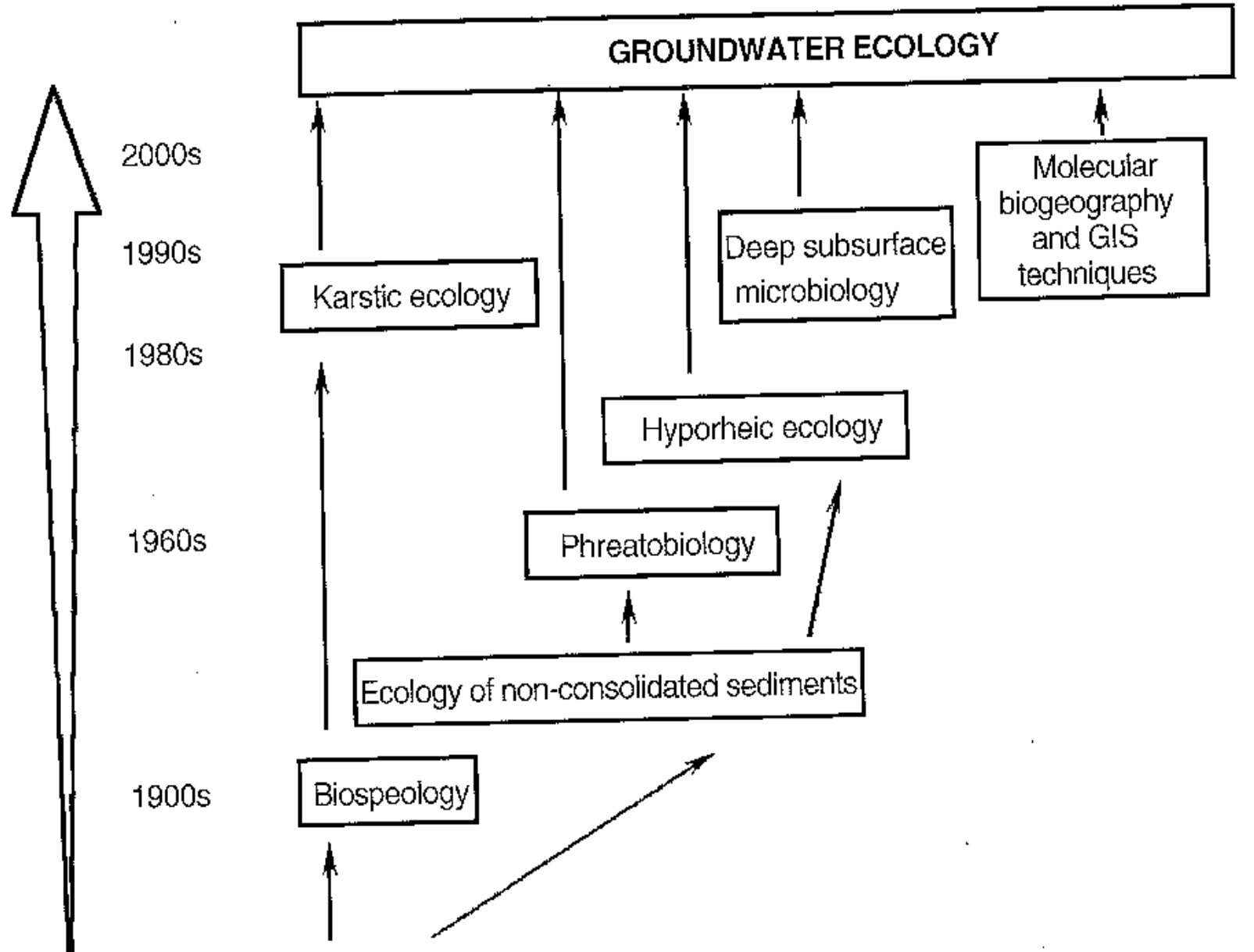

pre-1800s Discovery and descriptions of exclusively groundwater organisms

Fig. 1: The evolution of research perspectives in the development of groundwater ecology (Source: Gibert et al., 1994b) 
microorganisms play in determining water chemistry became well established (Kolbel-Boelke, et al., 1988). This humble beginning saw the birth of major applications of groundwater ecology- the cleaning of polluted groundwater by bioremediation (Piotrowsky, 1989; Wenderoth et al., 2003). Of special mention in the research efforts are the European groundwater researchers working in the mid-1900s. Inspite of these elegant research efforts, much recognition did not occur until the 1990s, when the International Groundwater Ecology Symposium was held in 1992 (Stanford \& Simons, 1992). The outcome of the symposium was the publication of the first textbook dedicated to the field (Gibert et al., 1994a). Fig.1 shows the evolution of research perspectives in the development of groundwater ecology.

Groundwater ecology has emerged formerly as a discipline quite recently (Gilbert, et al., 1994a, 1994b), but has gained recognition from international organizations such as the World Bank (Vermeulen \& Whitten, 1999) and the Council of Europe (1992). This is most comprehensively enshrined in the European Groundwater Directive (2006) to incorporate ecological knowledge gained from the various disciplines of groundwater science into schemes for environmental planning and policies, although not as comprehensive as that proposed by Danielopol et al., (2004). However, groundwater ecology has been built on a long tradition of research on groundwater (Chilton, 1894) and cave life (Racovita, 1907), especially in Europe (Chappuis, 1927; Delamare-Deboutteville, 1960) and North America (Packard, 1871). The recent integration of groundwater sciences, including hydrogeology and groundwater biology, addresses groundwater ecology on a broad scale and this has occurred in parallel with the recognition that biological diversity of groundwater is much greater than formerly appreciated and much more widespread (Sket, 1999; Culver \& Sket, 2000; Wilkens et al., 2000; Danielopol et al., 2000; Danielopol \& Pospisil, 2001).

\section{Ecological Assessment Versus Groundwater Ecosystems}

Groundwater systems are subject to frequent and ongoing threats caused by groundwater extraction and melioration and introduction of chemicals, nutrients, and organisms or due to the impact of temperature via discharge of heat and cooling waters (Sampat, 2000). Because of the difficult accessibility of groundwater ecosystems, the patchy distribution of its fauna, the high number of endemic species therein with difficult taxonomy, the limited data on fauna and microbiology, and the absence of various groups of organisms, indices which are routine for surface water systems (Lafont et al., 2001) cannot be directly transferred to groundwater ecosystems (Tomlinson et al., 2007). However, the essential step in the development of a groundwater ecosystem assessment scheme 
(Hancock et al., 2005) will need to consider state of the art procedures also used for surface aquatic environments, which includes: (1) a classification of aquifer types, (2) the definition of a good ecological status, and (3) a first prototype of an assessment scheme.

Classifications of groundwater systems are exclusively based on abiotic criteria such as petrographic-geological-structural or hydrogeochemical properties (Heath, 1982; Wendland et al., 2007). The classification scheme may serve as a starting point for the ecological investigations. For some group of organisms, i.e the groundwater invertebrates, their distribution may not always be linked to structural and physical -chemical properties of aquifers and groundwater only, but are, for example, subject to biogeographical patterns. Studies on groundwater fauna can also indicate local and regional aquifer characteristics such as the hydraulic exchange with surface waters and the import of organic matter, and the culmination of such input determines the community composition, rather than large-scale geological and hydrogeochemical patterns (Hahn, 2006).

On the whole, a sustainable groundwater ecosystem assessment scheme must be complemented with the bio/eco criteria, which ultimately must result in a common groundwater ecosystem evaluation concept. The pillars that must contribute to the assessment scheme, includes: (1) physical-chemical measures, (2) basic microbiological measures, (3) measures for the structure of microbial communities and ecological parameters such as microbial biodiversity, and (4) the groundwater fauna. Indices derived from these pillars may be applied independently similar to other concepts (Lafont et al., 2001; Rentier et al., 2006). However, one best option is to combine them after data weighting, normalization, and aggregation, to derive an integrative groundwater ecosystem index.

\section{Biodiversity in Groundwater}

Biodiversity simply refers to the variety and variability of life forms (plants, animals and mico-organisms) on earth (Mmom, 2009). The need for an in-depth understanding of biological diversity with respect to groundwater is very important for an integrative assessment of abiotic and biotic indicators. This is crucial in the assessment of the environmental status, in monitoring trends over time, in providing early warning of ecosystem deterioration, and in diagnosing the cause of an existing impact (Cairns et al., 1993).

The discovery of biological indicators and ecological criteria as well as the subsequent development of an ecologically based assessment scheme is not an easy task and will take some effort and time. This is so because microbial 
parameters do not exhibit simple correlations to the physical-chemical conditions. However, this is no surprise, as natural ecosystems are complex multivariate systems and are being simultaneously exposed to multitude of stresses, the mechanisms and cumulative effects of which are poorly understood (Cairns et al., 1993). This lack of correlation between abiotic and biotic components is a strong argument for consideration of biological and ecological criteria. It is to be noted that no single indicator can fulfill the expected purposes of (1) detection of an impact, (2) determination of its effect on the system, and (3) identification of its origin. The above information is required for the development of rehabilitation strategies and trend reversal. Thus, an integrative assessment needs a set of abiotic and biotic indicators to assess the environmental status, to monitor trends over time, to provide early warning of ecosystem deterioration, and to diagnose the cause of an existing impact (Cairns et al., 1993).

Though, it is not easy to derive reliable natural background values and variations for basic biological and ecological parameters, but it will be possible to identify useful criteria that are sensitive to impacts generally faced, for example, (1) diffusive loading of aquifers with nitrate and pesticides, (2) eutrophication via surface water intrusion (3) point sources of hazards like organic solvents and heavy metals, (4) chronic pollution with pharmaceuticals and endocrine active substances, and (5) contamination with pathogens. The possibility of identifying a set of groundwater microbial indicators is predicated on the fact that microorganisms and microbial assemblages have been shown to carry indicator skills in relation to eutrophication (Pearl et al., 2003), the influence of waste water and the presence of pathogens (Cho \& Kim, 2000; Foppen \& Schijven, 2006) as well as the activity of biodegradation pathways (Winderl et al., 2007). It is interesting to note that molecular methods provide the research tools to analyse shifts in miocrobial patterns in relation to changes in environmental conditions (Goldscheider et al., 2006). To make all these possible, there is the need to learn about natural variations of microbial variables. Biodiversity in groundwater is often considered severely constrained by low spatiotemporal heterogeneity and low food supply (Datry et al., 2005). However, spatial heterogeneity, exhibited at the macro, meso, and micro (Ronen et al., 1987) scales, is a reflection of both the aquifer structure and composition, the groundwater flow velocity, organic matter content, and the abundance and activity of microorganisms and stygo-fauna.

\section{Processes Threatening Groundwater Ecosystems}

Anthropogenic impacts on groundwater from an ecological viewpoint, have been categorized as either quantitative or qualitative (Danielopol et al., 2003). Quantitative impacts affect the volume or structure of the aquifer. Groundwater 
extraction including mine de-watering reduces the volume of saturated sediments while mining removes the sediment matrix (Hancock, 2002; Nwankwoala \& Odigi, 2008). Impacts on water quality in the aquifer include processes such as sea-water intrusion and pollution. Not only are these types of impacts seldom readily reversible, they often occur so gradually that they are hard to detect until damage has been done.

Excessive groundwater extraction may lower the water table of an aquifer so much that it serves as a link to the terrestrial ecosystems that rely on shallow groundwater to sustain them (Winter, 1999). The rapid hydrogeological changes brought about by encroaching human activities potentially threatens their existence in many areas. Compounding this threat is the highly localized distribution of many species (Marmonier et al., 1993) and their apparent susceptibility to some pollutants (Notenboom et al.,1994). Stygofauna (groundwater animals) play key roles in aquifers including the maintenance of interstitial voids, modification of redox gradients, and the promotion of biofilm activity (Humpherys, 2002; Gibert \& Deharveng, 2002). Therefore, their loss potentially compromises the functioning of the aquifer and its ecosystem, resulting in a decline in groundwater quality. Stygofauna communities in the hyporheic zone are particularly vulnerable to the development of both surface and groundwater resources (Boulton, 2000a, 2001; Hancock, 2002) but seldom are considered explicitly in restoration programs.

Given the right conditions, groundwater microbes have the ability to degrade some pollutants (Haack \& Bekins, 2000). However, degradation may not be rapid enough to prevent the occurrence of substantial impacts to other organisms within the aquifer, or those in connected ecosystems. The sensitivity of some stygofaunal species to pollution may mean that they can be used as biological monitors and indicators of declining water quality (Malard et al., 1996).

\section{Current Research Efforts in Groundwater Ecology}

Recent developments in groundwater ecology have led to more applied research in the field of bioremediation which takes the advantage of the ability of phreatic microbes to degrade pollutants. Bioremediation has been used to treat pollution from chlorobenzenes (Van der Meer et al., 1998; Wenderoth et al., 2003), pesticides (Hoyle \& Arthur, 2000), and hydrocarbons (Chapelle, 2001). While natural attenuation of contaminants occurs in many aquifers through biological degradation, dispersion, or dissolution, this often does not proceed at a rate that is desirable to humans. Bioremediation is a way of accelerating some of these natural processes, and for it to be successful the aquifer must contain the appropriate 
microorganisms and conditions favourable to degradative processes (Haack \& Bekins, 2000).

Currently, there are two popular bioremediation strategies: biostimulation and bioaugmentation. Biostimulation accelerates the degradative activity of indigenous bacterial communities by the addition of suitable electron donors/ acceptors or nutrients (Wenderoth et al., 2003). This process relies on the existing bacterial community being able to degrade pollutants. Bioaugmentation, on the other hand, is when bacteria are added to aquifers to assist bioremediation. This has had more success under laboratory conditions and with soil remediation than in aquifers because the introduced bacteria are often unable to survive for long periods in the aquifer (Chapelle, 2001). It should be noted that species translocations, such as occur with bioaugmentations, might have deleterious impacts on the natural ecosystem as seen in other exotic species introduction in surface ecosystems (Hancock et al., 2005).

The synthesis of detailed studies concerning the central role of hydrological exchange between groundwater and river water in governing the chemistry and fauna of the hyporheic zones, and even that of surface water where hyporheic upwelling occurred (Valett et al., 1993). This development brought hydrogeologists and groundwater ecologists together to integrate their findings and explore catchment-scale concepts such as nutrient spiraling and retention in terms with porous sediments (Jones \& Mulholland, 2000). Substantial technological advances in the use of tracers and groundwater modeling approaches now make it possible to collate hydrological data on pathways and residence time with ecological variables of water chemistry, faunal composition or microbial activity (Hancock, 2004).

The ecotone (transition zone between two ecosystems that displays characteristics of both) approach to groundwater ecology led to a functional classification of hyporheic invertebrates into three broad groups based on their affinity to the groundwater habitat (Marmonier et al., 1993). The groups include: stygoxen (largely confined to surface water), stygophile (able to spend part of its life in the hyporheic zone but without adaptations for subterranean life), and stygobite (obligated to complete its life cycle in groundwater, with adaptations to do so). This classification has been successfully used to illustrate the linkages between groundwater and surface water, and to reveal the impacts of human activities, such as river regulation that alter these linkages (Claret et al., 1999).

The most pressing application of hydrogeology in the context of groundwater ecology relates to the testing of the generality of conceptual models proposed as a 
framework for cross-ecosystem comparisons of groundwater-surface water interactions in standing and flowing waters. One such framework was developed to account for different ratios of subsurface meiofauna to microfauna, and how their biological activities might affect the exchange of material between surface and groundwaters (Boulton, 2000b). The framework commences with predictions of changes along an axis corresponding to particle sizes ranging from fine sediments in the depositional zones of standing waters to the coarse sediments in streams where there is strong throughflow. This framework must be viewed in the context of the effects of disturbances such as spates that would cause burial, and the final model attempted to integrate disturbance frequency but remains to be tested. Not only can hydrogeologists assist with measurements and modeling of the interface characteristics at different flows, there is scope to expand these models to catchment scales. This will allow prediction of the changes that would occur along gradients of sediment particle size and disturbance frequency along a river where groundwater-surface water interactions occur. Where disturbances are low and sediments are fine, the fauna may play a disproportionately important role in facilitating exchanges or altering the sediment matrix and this ecological aspect could be incorporated into the hydrogeological model. It is suggested that most current hydrogeological models of groundwater systems do not explicitly include relevant ecological aspects such as stygofaunal activity or microbial processes.

\section{Challenges and Future Perspectives}

Following the issues raised in this paper, it is very obvious that the contributions of groundwater ecology to ecological sustainability cannot be overemphasized. Like any other field, there are certain challenges. For instance, in biomonitoring which is widely used to evaluate the quality of surface waters and which appears to be an interesting approach for groundwater needs more clarification. Biomonitoring, which is a valuable supplementary tool for controlling groundwater quality, delivers more integrated, but less quantitative information than chemical analyses. Bacteria are the dominant organisms in aquifers, and their occurrence and activity is related to the biogeochemical conditions. The structures of microbial communities, individual marker organisms, or even specific functional genes are therefore promising bioindicators. However, there is often a complex relation between water quality and microbial communities, and their responses to specific contaminants are poorly understood.

Short-term microbial contamination such as those resulting from storm events can be easily detected by in-situ monitoring of natural physical and chemical parameters. However, the long-term monitoring of autochthonous endokarst 
microbial communities during years or decades may be an interesting approach to assess the general water quality and to detect potential changes in ecosystem functioning due to chronic low level contamination or climate change. The applied molecular methodology does not have the required resolution and throughput for monitoring purposes yet, but new, promising techniques are continuously being developed (Chandler \& Jarrel, 2004; He et al., 2007; Roesch et al., 2007).

Finston et al., (2007), using molecular methods, found groundwater tributaries of palaeodrainage systems with episodic surface flow to contain groundwater amphipod populations that have been separated for between 2.0-8.9 ma, indicating that these tributaries cannot serve as refugia for species inhabiting the palaeodrainage system. The extent to which this is true for recent tributaries within a catchment is poorly understood.

There is an increasing recognition of the existence of numerous terrestrial and marine ecosystems partially or wholly reliant on groundwater. These Groundwater Dependent Ecosystems (GDEs) include some communities of terrestrial vegetation, river baseflow systems, standing wetlands with subsurface linkages to the groundwater table, various terrestrial faunal communities (particularly in arid zones), and many esturine and near-shore marine ecosystems where groundwater outwells (Cliften \& Evans, 2001). The degree of ecosystem dependence differs among each category, and varies seasonally and annually - some GDEs may only be reliant on groundwater during drought (Boulton, 2000b). However, the common thread linking all of these ecosystems is their hydrological connection to the aquifer. Less well understood is the way these links are governed by the hydrogeology of the GDE, and this would, of necessity be a productive line of research in future, more especially in the prediction of the location of GDEs in poorly- mapped areas.

Moreso, a considerable number of studies have also proved the possible application of groundwater invertebrates as indicators for environmental changes and anthropogenic impacts. On the other hand, knowledge of the taxanomy, distribution and ecology of groundwater fauna is still poor (Tomlinson et al., 2007). There is the need to timely relate microbial patterns with the data from groundwater fauna.

The educational aspect is very important for managers of groundwater resources. For groundwater use to be sustainable, it must be supported by relevant, highquality research that addresses water resource needs and answers critical questions about the factors that control water quality as well as volume. This of course, will 
require constant liaison among managers, hydrogeologists, and ecologists to identify and fill existing knowledge gaps. Comparatively, more is known about the factors that influence groundwater volume and availability than about the processes that maintain its quality. It is likely that many biological processes (especially microbial) largely govern groundwater quality, as can be seen in the field of bioremediation. One significant contribution of hydrogeology in the future will be to understand how matrix structure, interstitial flow, and other hydrogeological aspects in different groundwater ecosystems control microbial activity. There is considerable scope for experimental manipulation of these variables, both in mesocosms in the laboratory as well as in aquifers where mining of natural resources and other activities will affect groundwater levels. Adaptive environmental management approaches (Gunderson \& Holling, 2001) that take advantage of monitoring hydrogeological and ecological responses to human activities potentially affecting groundwater are the obvious arena for tight collaboration.

Indeed, the culmination of the above approaches and concepts from the 1990s is the current integrative discipline of groundwater ecology that incorporates the fields of hydrology, geology, biology and more recently sustainable management of the groundwater resources. One of the most obvious challenge for the future is to consider how each of these fields can help one draw generalizations about processes occurring in the broad diversity of groundwater ecosystems and to advance our understanding by using a range of methods borrowed from other disciplines, which will ultimately make it necessary to appreciate the diversity of groundwater environments.

\section{Conclusions}

No doubt, groundwater ecology is a societally relevant and necessary science. It is worth emphasizing that groundwater ecological links can be wide-ranging, as this paper noted, including not only such well recognized areas of water-plant interactions or groundwater-temperature-trout relations, but also less well known areas such as microbial community characterization at the periphery of contaminant plume. The prediction of groundwater biodiversity and the distribution of important or endangered species also rest squarely on this field. In view of the importance of this emerging discipline, there is the need to recognize that the skill set for true interdisciplinary "hydrogeoecology" spans more than any one person can hope to achieve in a lifetime of learning. Inevitably, there needs to be research that uses teams of scientists, and excellent work plans and budgets that should reflect this reality. 
Ultimately, more than anything else, much of the work done by researchers must meet the needs of resource managers and society. Groundwater ecology epitomizes the holistic approach required to truly meet these needs. It should be our collective charge to develop the discipline to realize this result. The scientific problems and technical challenges as described in this paper are fundamentally important for advancement of human knowledge and ecological understanding of groundwater. This paper therefore, echoes and advocates for the need for researchers and managers to work together to develop relevant, innovative and tractable research questions and directions that will promote more effective consideration of the ecological consequences of hydrogeological decisions. It is hoped that this paper, as earlier noted, has set the stage for the promotion of further partnerships of hydrogeologists and ecologists in this new field of hydrogeoecology. More importantly, this paper contends that both discipline has much to learn from each other, and that working together will help in achieving a better management outcomes for the sustainable utilization, conservation, and remediation of groundwater, a resource that is often over-exploited and contaminated, but on which humankind is increasingly dependent.

\section{References}

BOULTON, A.J. 2000a. River ecosystem health down under: assessing ecological condition in riverine groundwater zones in Australia. Ecosystem Health 6: 108118.

BOULTON, A.J. 2000b. The subsurface macrofauna. In: Jones J, Mulholland P (eds.) Streams and Groundwaters. Academic Press, New York, pp 337- 361.

BOULTON, A.J. 2001. Twist two worlds: taxonomic and function biodiversity at the surface water/groundwater interface. Rec Aust Mus Supp 64:1-13

CAIRNS, (Jr.) J; MCCORMICK, P.V; NEIDERLEHNER, B.R., 1993. A proposed framework for developing indicators of ecosystem health. Hydrobiologia263:1-44

CHANDLER, D.P \& JARRELL, A.E., 2004. Automated purification and suspension array detection of $16 \mathrm{~S}$ rRNA fron soil and sediment extracts by using tunable surface microparticles. Appl Environ Microbiol 70(5):2621-2631

CHAPELLE, F.H., 2001. Groundwater Microbiology and Geochemistry, $2^{\text {nd }}$ edn. Wiley, New York.

CHAPPUIS, P.A., 1927. Die Tierwelt der Unterirdischen Gewasser. Binnengewasser 3:1175

CHILTON, C., 1894. The subterranean Crustacea of New Zealand, with some general remarks on the fauna of caves and wells. Trans Linn Soc Lond Ser 2 Zool 6:1623 
CHO, J.C \& KIM, S.J., 2000. Increase in bacterial community diversity in subsurface aquifers receiving livestock wastewater input. Appl Environ Microbiol 66:956965

CLARET, C; MARMONIER, P; DOLE-OLIVIER, M.J; CREUZE des CHATELliERS, M; BOULTON, A.J; CASTELLA, E., 1999. A functional classification of interstitial invertebrates: supplementing measures of biodiversity using species traits and habitat affinities. Arch Hydrobiol 145: 385-403.

CLIFTON, C \& EVANS, R., 2001. Environmental flow requirements of groundwater dependent ecosystems. Environmental flows initiative technical report number 2, Commonwealth of Australia.

COUNCIL OF EUROPE., 1992. Convention on the conservation of the wildlife and natural environment of Europe Criteria for the selection of subterranean habitat of biological interest. Recommendation No 36 (1992) on the conservation of subterranean habitats Annexe 1 to the recommendation. Council of Europe, Bruxelles

CULVER, D.C \& SKET, B., 2000. Hotspots of Subterranean biodiversity in caves and wells. J Caves Karst Stud 62:11-17

DANIELOPOL, D.L \& POSPISIL, P., 2001. Hidden biodiversity in the groundwater of the Danube Flood Plain National Park (Austria). Biodivers Conserv. 10:17111721

DANIELOPOL, D.L., 1994. What can we expect from groundwater ecologists? In: Stanford, J.A; Valett, H.M (ed.) Proc Second Internat Groundwat Ecol Conf, pp13-20

DANIELOPOL, D.L; GRIEBLER, C; GUNATILAKA, A., 2007. Incorporation of groundwater ecology in environmental policy. In: Quevauviller P (eds.) Groundwater science and policy. Royal Society of Chemistry, London, pp671689

DANIELOPOL, D.L; GRIEBLER, C; GUNATILAKA, A; NOTENBOOM, J., 2003. Present state and future prospects for groundwater ecosystems. Environ Conserv 30:104-130

DANIELOPOL, D.L; POSPISIL, P; ROUCH, R., 2000. Biodiversity in groundwater: a large- scale view. Trends Ecol Evol 15:223-224

DATRY, T; MALARD, F; GIBERT, J., 2005. Response of invertebrate assemblages to increased groundwater recharge rates in a phreatic aquifer. J.N Am Benthol Soc 24:461-477

DELAMARE- DEBOUTTEVILLE, C., 1960. Biolgie des eaux souterraines lithorales et continentals (Biology of lithoral and continental subterranean water). Hermann, Paris

EUROPEAN GROUNDWATER DIRECTIVE., 2006. Directive 2006/118/ECEU GWD, of the European Parliament and of the Council of 12 December 2006. Off J Eur Comm L 372: (19) 
FINSTON, T.L; JOHNSON, M.S; HUMPHREYS, W.F., 2007. Crytic speciation in two widespread subterranean amphipod genera reflects historical drainage patterns in an ancient landscape. Mol Ecol 16:355-365

FOPPEN,JWA \& SCHIJVEN, J.F., 2006. Evaluation of data from the literature on the transport and survival of Esherichia coli and thermotolerant coliforms in aquifers under saturated conditions. Wat Res 40:401-426

GIBERT, J \& DEHARVENG, L., 2002. Subterranean ecosystems: a truncated functional biodiversity. BioScience 52:473-481

GIBERT, J; DANIELOPOL, D.L \& STANFORD, J.A., 1994a. Groundwater Ecosystems. In: Gilbert, J; Danielopol, D.L; Stanford, J.A (eds.) Groundwater ecology. Academic Press, London, pp23 - 39.

GIBERT, J; STANFORD, J.A; \& DOLE-OLIVER M-J., 1994b. Basic attributes of groundwater ecosystems and prospects for research. In: Gibert, J; Danielopol, D.L; Stanford, J.A (eds.) Groundwater ecology. Academic, London, pp7-40

GOLDSCHEIDER, N; HUNKELER, D \& ROSSI, P., 2006. Review: microbial biocenoses in pristine aquifers and an assessment of investigative methods. Hydrogeology J 14: 231- 242.

GUNDERSON, L.H \& HOLLING, C.S., 2001. Panarchy: understanding transformation in systems of humans and nature. Island Press, New York

GUREVICH, M.S., 1962. The role of microorganisms in producing the chemical composition of groundwater. In: Kuznetsov, S.I (ed) Geologic activity of microorganisms. Trans Institut Microbiol, New York IX: $65-67$.

HAACK, S.K \& BEKINS, B.A., 2000. Microbial populations in contaminant plumes. Hydrogeol J 8:63-76

HAHN, H.J., 2006. The GW-fauna-index: a first approach to a quantitative ecological assessment of groundwater habitats. Limnologia 36:119-139

Hancock, P. 2002. Human impacts on the stream-groundwater exchange zone. Environ Manag 29:761-781

HANCOCK, P.J; BOULTON, A.J \& HUMPHERYS, W.F., 2005. Aquifers and hyporpheic zones: towards an ecological understanding of groundwater: the future of hydrogeology. Hydrogeology J 13:98-111

HANCOCK, P., 2004. The effects of river stage fluctuations on the hyporheic and parafluvial ecology of the Hunter River, New South Wales. PhD Thesis, University of New England, Armidale

HE Z; GENTRY, T.J; SCHADT, C.W, WU,L; LIEBICH, J; CHONG, S.C; HUANG, Z; WU, W; GU, B; JARDINE, P; GRIDDLE, C; \& ZHOU, J., 2007. GeoChip: a comprehensive microarray for investigating biogeochemical, ecological and environmental processes. ISME J 1(1):67-77

HEATH, R.C., 1982. Classification of groundwater systems of the United States. Groundwater 20:393-401

HOYLE, B.L \& ARTHUR, E. L., 2000. Biotransformation of pesticides in saturated zone materials. Hydrogeol J 8: 89 - 103. 
HUMPHREYS, W.F., 2002. Groundwater Ecosystems in Australia: an emerging understanding. Proc International Association Hydrogeologists Conference, pp 1 -14 .

JONES, B \& MULHOLLAND, P.J., 2000. Streams and Groundwaters, Academic, San Diego, CA

KOLBEL- BOELKE, J; ANDERS, E.M \& NEHRKRORN, A., 1988. Microbial communities in the saturated groundwater environment. 11: Diversity of bacterial communities in a Pleistocene sand aquifer and their in vitro activities. Microb Ecol 16: 31-48

LAFONT, M; CAMUS, J.C; FOURNIER, A \& SOURP, E., 2001. A practical concept for the ecological assessment of aquatic ecosystems: application on the River Dore in France, Aquat Ecol 35:195-205

MALLARD, F; MATTIEU, J; REYGROBELLET, J.L \& LAFONT, M., 1996. Biomonitoring groundwater contamination: Application to a Karst area in Southern France. Aquat Sci 58:159-187

MARMONIER, P; VERVIER, P; GIBERT, J \& DOLE-OLIVER, M.J., 1993. Biodiversity in groundwaters. Trends Ecol Evol8:392-395.

MMOM, P.C 2009. Threat to Biodiversity- Threat to Human Race. Environmental Manager, Vol.2, No.1, pp17-21

NOTENBOOM, J; PLENET, S \& TURQUIN, M.J., 1994. Groundwater contamination and its impact on groundwater animals and ecosystems. In: Gibert, J, Danielopol, D.L \& Stanford, J.A (eds.) Groundwater ecology. Academic Press, San Diego, 477-504

NWANKWOALA, H.O \& ODIGI, M.I., 2008. Hydrogeological problems caused by mineral exploration and mining in Nigeria. Journal of Nigerian Environmental Society, Vol.4(4):66-75

PACKARD, A.S., 1871. On the crustaceans and insects. Am Nat 5:744-761

PEARL, H.W; DYBLE, J; MOISANDER, P.H; NOBLE, R.T; PIEHLER,M.F; PINCKNEY, J.L; STEPPE, T.F; TWOMEY, L \& VALDES, L.M., 2003. Microbial indicators of aquatic ecosystem change: current applications to eutrophication studies. FEMS Microbiol Ecol 46:233-246

PIOTROWSKY, M.R., 1989. Bioremediation: Testing the waters. Civ Eng 59:51-53

RACOVITZA, E.G., 1907. Essai sur les problemes biospeologiques (Essay on biospeleogical problems). Biospeologica 1. Arch Zool Exp Gen 4: 371-488

RENTIER, C; DELlOYE, F; BROUYERE, S \& DASSARGUES, A., 2006. A framework for an optimized groundwater monitoring network and aggregated indicators. Environ Geol 50:194-201

ROESCH, L.F; FULTHORPE,R.R; RIVA, A; CASELLA, G; HADWIN, AKM; KENT, A.D; DAROUB, S.H; CAMARGO, F.A.O; FARMERIE, W.G; TRIPLTT, E.W 2007. Pyrosequencing enumerates and contrasts soil microbial diversity. ISME J 1(4):283-290

ROMERO, A., 2001. Scientists prefer them blind: the history of hypogean fish research. Environ Biol Fish 62L:43-71 
RONEN,D; MAGARITZ, M; ALMON, E., 1987. Anthropogenic anoxification ('Eutrophication') of water table in a deep phreatic aquifer. Water Resour Res 23: $1554-1560$

SAMPAT, P., 2000. Deep trouble: the hidden threat of groundwater pollution. World Watch Paper No. 154, World Watch, Washington, DC, 55pp

SKET, B., 1999. The nature of biodiversity in hypogean waters and how it is endangered. Biodivers Conserv 8:1319-1338

STANFORD, J.A \& SIMONS, J., 1992. Biological diversity of Groundwater. Proceedings of the First International Conference on Groundwater Ecology, Marryland, American Water Resources Association.

TOMLINSON, M; BOULTON, A.J; HANCOCK, P.J; \& COOK, P.J., 2007. Delibrate omission or unfortunate oversight: should stygofaunal surveys be included in routine groundwater monitoring programs? Hydrogeol. J 15:1317-1320

VALET, H.M; HAKENKAMP, C.C \& BOULTON, A.J., 1993. Perspectives on the hyporheic zone: integrating hydrology and biology. J N Am Benthol Soc 12:4043

VAN DER MEER, J.R; WERLEN, C; NISHINO, S.F \& SPAIN, J.C., 1998. Evolution of a pathway for chlorobenzene metabolism leads to natural attenuation in a contaminated aquifer. Appl Environ Microbiol 64:4185-4193

VERMEULEN, J \& WHIT'TEN, T., 1999. Biodiversity and cultural property in the management of limestone resources: Lessons from East Asia. The World Bank, Washington, DC

WENDEROTH, D.F; ROSENBROCK, P; ABRAHAM, W.R; PIPER, D.H \& HOFLE, M.G., 2003. Bacterial community dynamics during biostimulation and bioaugmentation experiments aiming at chlorobenzene degradation in groundwater. Microb Ecol 46:161-176

WENDLAND, F; BLUM, A; COESTSIERS, M; GOROVA, R; GRIFFIOEN, J; GRIMA, J; HINSBY, K; KUNKEL, R; MARANDI, A; MELO, T; PANAGOPOULOS, A; PAUWELS, H; RUISI, M; TRAVERSA, P; VERMOOTEN, J.S.A \& WALRAEVENS, K., 2007. European aquifer typology: a practical framework for an overview of major groundwater composition at European scale. Environ Geol. Doi: 10.1007/s00254-007-0966-5

WINDERL, C; SCHAFER, S \& LUEDERS, T., 2007. Detection of anaerobic toluene degraders in contaminated aquifers using benzylsuccinate synthase (bssA) genes as a specific functional marker. Environ Microbiol 9:1035-1046

WINTER, T.C., 1999. Relation of streams, lakes, and wetlands to groundwater flow systems. Hydrogeol J 7:28-45. 